Gut, 1973, 14, 485-490

\title{
The influence of secretin on ion transport in the human jejunum
}

\author{
T. HICKS AND L. A. TURNBERG \\ From the Division of Gastroenterology, The Royal Infirmary, Manchester
}

SUMMARY Using a triple-lumen tube perfusion technique in normal human subjects secretin ( $2 \mathrm{U} / \mathrm{kg} /$ hour intravenously) was shown to reduce the absorption of sodium, potassium, and chloride in the most proximal $30 \mathrm{~cm}$ of jejunum but it had no effect on bicarbonate absorption. This effect was not due to an artefact produced by the entry of secretin-stimulated, bicarbonate-rich, pancreatic juice into the test segment. Absorption of sodium chloride and water was stimulated rather than inhibited by higher bicarbonate concentrations and the effect of secretin was obvious even when this factor was controlled by adjusting the bicarbonate concentrations of the test fluids. Secretin did not influence ion transport in the mid-jejunum. It is suggested that the effects described may indicate a physiological role for secretin in the intestine where it could prevent the too rapid dehydration of upper jejunal contents which might interfere with adequate mixing and digestion.

The effects of secretin on electrolyte secretion by the pancreas, biliary tree, and stomach are well recognized (Wormsley, 1968; Jonson, Sundman, and Thulin, 1964; Johnson and Grossman, 1971). There are, however, conflicting data on the effect of secretin on intestinal transport (Modigliani, Huet, Rambaud, and Bernier, 1971; Mekhjian, King, Sanzenbacher, and Zollinger, 1972; Moritz, Finkelstein, Meshkinpour, Fingerut, Siplet, and Lorber, 1972; Gardner, Peskin, Cerda, and Brooks, 1967; Barbezat and Grossman, 1971) and the present studies were performed to delineate more clearly its influence in the human jejunum and to assess the possibility that it is involved in the normal control of intestinal ion movement.

\section{Methods}

Thirty-seven normal human adult volunteers who were fit undergraduate and postgraduate students aged 18 to 40 years were investigated using the triple-lumen tube perfusion technique of Ingelfinger (Cooper, Levitan, Fordtran, and Ingelfinger, 1966). This is an open-ended system which incorporates a $10 \mathrm{~cm}$ mixing segment to allow for endogenous secretions which enter the intestine from above. Test solutions were infused into the intestine at a constant rate and intestinal contents were con-

Received for publication 13 March 1973. tinuously sampled, $10 \mathrm{~cm}$ and $40 \mathrm{~cm}$ distal to the point of infusion. Any changes in concentration which took place between the two aspiration sites must have occurred because of absorption or secretion within the segment of intestine lying between them. Since the proximal aspiration point always lay at least $20 \mathrm{~cm}$ distal to the ampulla of Vater, pancreatic and biliary secretion, although influencing the flow rate of fluid into the test segment of intestine, cannot be responsible for changes in concentration which occurred between the two aspiration sites. Any measured absorption or secretion thus occurs within the segment of intestine studied.

Electrolyte and non-absorbable marker concentrations were measured in samples taken from the two aspiration sites. The volumes of fluid entering and leaving the test segment were calculated using the following equations:

$$
V_{E}=\frac{V_{I} \times[M] i}{[M] p}-S p
$$

and

$$
\mathrm{V}_{\mathrm{L}}=\frac{\mathrm{V}_{\mathbf{E}} \times[\mathrm{M}] \mathrm{p}}{[\mathrm{M}] \mathrm{d}}
$$

where $V_{E}=$ volume entering, $V_{I}=$ infusion rate, and $V_{L}=$ volume leaving the test segment and $[M] i,[M] p$, and $[M] d=$ the marker concentration in the infusate, and in the samples aspirated from the 
proximal and distal aspiration sites. $\mathrm{Sp}=$ the volume of the sample withdrawn from the proximal site.

The net volume absorbed or secreted by the test segment of intestine was given by subtracting $V_{L}$ from $V_{E}$. The net amount of electrolyte absorbed or secreted was calculated by:

$$
V_{E} \times[A]_{E}-V_{L} \times[A]_{L}
$$

where $A_{E}$ and $A_{L}$ are the concentrations of electrolyte in the fluid entering and leaving the segment respectively.

The tube was swallowed the night before the study and after an overnight fast the position of the tube was checked radiologically. In most studies the investigations were started when the infusion point was at the duodeno-jejunal junction but in some the tube was allowed to move on a further 30 to $40 \mathrm{~cm}$ into the mid jejunum. All solutions were infused at $11 \mathrm{ml} / \mathrm{min}$ and, after a 30-minute equilibration period, samples were collected continuously for 60 minutes. Two consecutive studies were performed on the same individual and, in the second period, secretin was infused intravenously during the whole period. The secretin used was obtained from G.I.H. Laboratories, Karolinska Institutet, Stockholm, and was infused in a dose of $2 \mathrm{U} / \mathrm{kg} / \mathrm{hr}(0.5 \mu \mathrm{g} / \mathrm{kg} / \mathrm{hr})$ for the 30 minutes' equilibration period and the 60 minutes of the collection period.

Infusion solutions were all isotonic and contained $5 \mathrm{~g} / \mathrm{l}$ of the poorly absorbed water-soluble marker polyethylene glycol 4000 (PEG). They contained $\mathrm{NaCl}, \mathrm{NaHCO}_{3}$, and $\mathrm{KCl}$, in varying concentrations as shown in table I.

Sodium and potassium were measured using an
EEL flame photometer, chloride with an EIL chloridometer, total carbon dioxide with a Natleson microgasometer, osmolality with an Osmette osmometer, and PEG using the turbidometric method of Hyden (1956).

Total bile salt concentrations were measured, using the method of Turnberg and Anthony-Mote (1969), in samples of the perfusate entering the test segment during control and secretin periods on five occasions (study 2).

\section{Results}

\section{STUDY 1}

The results of two consecutive control studies with identical test solutions are shown in table II and indicate that no statistically significant variation in ion or water transport rates occurred although the mean values were slightly lower during the second period.

\section{STUDY 2}

The results of studies in which secretin was given after a control period indicate that secretin reduced absorption of sodium, potassium, chloride, and water and this reduction was statistically significant $(\mathrm{P}<0.05)$ (table III).

It should be noted, however, that since a bicarbonate-rich fluid, arising from the pancreas during secretin stimulation, mixed with the infusion solution proximal to the test segment, the mean bicarbonate concentration of fluid entering the segment was higher than during the control period. The mean concentrations of sodium and potassium were

\begin{tabular}{|c|c|c|c|c|c|c|c|c|}
\hline & \multicolumn{2}{|c|}{$\begin{array}{l}\text { Study } 1(n=5) \\
\text { and } \\
\text { Study } 5(n=8)\end{array}$} & \multicolumn{2}{|c|}{ Study $2(n=5)$} & \multicolumn{2}{|c|}{ Study $3(n=10)$} & \multicolumn{2}{|c|}{ Study $4(n=9)$} \\
\hline & Control & Control & Control & Secretin & Control & Control & Control & Secretin \\
\hline $\begin{array}{l}\mathrm{NaCl} \\
\mathrm{NaHCO}_{3}\end{array}$ & $\begin{array}{l}95 \\
45\end{array}$ & $\begin{array}{l}95 \\
45\end{array}$ & $\begin{array}{l}95 \\
45\end{array}$ & $\begin{array}{l}95 \\
45\end{array}$ & $\begin{array}{r}105 \\
35\end{array}$ & $\begin{array}{l}80 \\
60\end{array}$ & $\begin{array}{l}95 \\
45\end{array}$ & $\begin{array}{r}140 \\
0\end{array}$ \\
\hline
\end{tabular}

Table I Electrolyte concentrations in $m M / l$ used in the five types of study 1

${ }^{1}$ Each solution also contained $\mathrm{KCl} 5 \mathrm{mM} / 1$ and PEG $5 \mathrm{~g} / \mathrm{l}$.

\begin{tabular}{|c|c|c|c|c|c|c|c|c|c|}
\hline & \multicolumn{4}{|c|}{ Mean Concentrations (m-equiv/l) in Test Segment } & \multicolumn{5}{|c|}{ Mean Net Transport Rates (m-equiv or $\mathrm{ml} /$ hour $/ 30 \mathrm{~cm}$ ) } \\
\hline & $\mathrm{Na}^{+}$ & $\boldsymbol{K}^{+}$ & $\mathrm{Cl}^{-}$ & $\mathrm{HCO}_{3}^{-}$ & $\mathrm{Na}^{+}$ & $\boldsymbol{K}^{+}$ & $\mathrm{Cl}^{-}$ & $\mathrm{HCO}_{3}^{-}$ & $\mathrm{H}_{2} \mathrm{O}$ \\
\hline $\begin{array}{l}\text { Control } 1 \\
\text { Control } 2\end{array}$ & $\begin{array}{l}134 \cdot 4 \pm 1 \cdot 16 \\
135 \cdot 9 \pm 0 \cdot 59\end{array}$ & $\begin{array}{l}5.02 \pm 0 \cdot 31 \\
4 \cdot 68 \pm 0 \cdot 18\end{array}$ & $\begin{array}{l}119 \pm 1 \cdot 95 \\
118 \cdot 8 \pm 2 \cdot 18\end{array}$ & $\begin{array}{l}18 \cdot 15 \pm 1 \cdot 25 \\
20 \cdot 24 \pm 1 \cdot 89\end{array}$ & $\begin{array}{l}-18.4 \pm 4.4 \\
-14.2 \pm 1.9\end{array}$ & $\begin{array}{l}-0.78 \pm 0.2 \\
-0.64 \pm 0.12\end{array}$ & $\begin{array}{l}-9 \cdot 6 \pm 2 \cdot 5 \\
-6.8 \pm 1 \cdot 0\end{array}$ & $\begin{array}{l}-9 \cdot 4 \pm 2 \\
-7 \cdot(4 \pm) \cdot 7\end{array}$ & $\begin{array}{l}-136 \cdot 2 \pm 26 \cdot 5 \\
-104.8 \pm 14.5\end{array}$ \\
\hline Significance & NS & NS & NS & NS & NS & NS & NS & NS & NS \\
\hline
\end{tabular}

Table II Results of two consecutive control studies (study 1) in which identical test solutions were infused and no secretin was given ${ }^{1}$

${ }^{1}$ Mean values \pm 1 standard error are shown; - ve sign indicates net absorption, + ve sign indicates net secretion in this and subsequent tables. NS indicates no significant difference: $n=5$. 


\begin{tabular}{|c|c|c|c|c|c|c|c|c|c|}
\hline & \multicolumn{4}{|c|}{ Mean Concentrations (m-equiv/l) in Test Segment } & \multicolumn{5}{|c|}{ Mean Net Transport Rates (m-equiv or $\mathrm{ml} / \mathrm{hr} / 30 \mathrm{~cm}$ ) } \\
\hline & $\mathrm{Na}^{+}$ & $\boldsymbol{K}^{+}$ & $\mathrm{Cl}^{-}$ & $\mathrm{HCO}_{3}^{-}$ & $\mathrm{Na}^{+}$ & $\boldsymbol{K}^{+}$ & $\mathrm{Cl}^{-}$ & $\mathrm{HCO}_{3}^{-}$ & $\mathrm{H}_{2} \mathrm{O}$ \\
\hline $\begin{array}{l}\text { Control } \\
\text { Secretin }\end{array}$ & $\begin{array}{l}135 \cdot 1 \pm 2 \cdot 65 \\
139 \pm 1 \cdot 41\end{array}$ & $\begin{array}{l}5.49 \pm 0.22 \\
4.84 \pm 0.2\end{array}$ & $\begin{array}{l}114.9 \pm 1 \cdot 87 \\
106 \cdot 6 \pm 4 \cdot 73\end{array}$ & $\begin{array}{l}19 \cdot 32 \pm 2 \cdot 55 \\
33 \cdot 34 \pm 5 \cdot 41\end{array}$ & $\begin{array}{l}-16.4 \pm 0.23 \\
+0.6 \pm 5.2\end{array}$ & $\begin{array}{l}-0.93 \pm 0.23 \\
-0.06 \pm 0.26\end{array}$ & $\begin{array}{l}-8 \cdot 5 \pm 2 \cdot 9 \\
+4 \cdot 1 \pm 2 \cdot 9\end{array}$ & $\begin{array}{l}-8.75 \pm 1.52 \\
-4.22 \pm 2.48\end{array}$ & $\begin{array}{l}-142.9 \pm 35 \\
-0.02 \pm 36.9\end{array}$ \\
\hline Significance & NS & NS & $\mathbf{P}<0.05$ & $P<0.02$ & $P<0.05$ & $P<0.05$ & $P<0.05$ & NS & $P<0.05$ \\
\hline
\end{tabular}

Table III Effect of secretin on net transport rates in five subjects when infusion solutions contained equal bicarbonate concentrations ${ }^{1}$

${ }^{1}$ Note that the mean bicarbonate concentration of the solution within the jejunal lumen was higher during secretin infusion than in the control period because of the addition of pancreatic bicarbonate to the test solution.

similar during both periods, while chloride concentrations varied reciprocally with bicarbonate.

\section{sTUDY 3}

An attempt was made to assess the possible effect of this factor on ion transport in a series of 10 studies in which no secretin was infused but a higher bicarbonate-containing fluid was infused during a second control period. The results (table IV) indicate that the higher bicarbonate during the second control period was associated with a statistically significant increase in absorption of sodium, potassium, bicarbonate, and water. Chloride absorption rose but the increase was not statistically significant. The decrease in absorption induced by secretin in the face of a higher bicarbonate concentration thus assumes a greater significance.

The rates of sodium and water absorption in the initial control period of these studies is lower than in control periods of studies 1,2 , and 4 . This may be at least partly explained by differences in the infusion solutions which contained a lower bicarbonate concentration in this study than in the others (table I).

\section{STUDY 4}

A further series of studies was performed in which the mean bicarbonate concentration within the test segment of intestine was maintained at a similar level in both control and secretin periods by adjusting the concentration in the infusion solutions. Bicarbonate arising from the pancreas brought up the mean concentration during the secretin period to a similar level to that during the control period, and the difference in the measured mean bicarbonate concentrations in the test segments was not significant (table V). The results (table V) confirm that secretin reduces absorption of sodium, chloride, potassium, and water. The reduction in water and chloride absorption was statistically significant while the reduction in sodium and potassium absorption just failed to reach statistical significance. Bicarbonate absorption was unchanged by secretin when the mean bicarbonate concentration was thus controlled.

\section{STUDY 5}

In eight subjects the tube was allowed to move on a further $30-40 \mathrm{~cm}$ down the intestine for a study of

\begin{tabular}{|c|c|c|c|c|c|c|c|c|c|}
\hline & \multicolumn{4}{|c|}{ Mean Concentrations (m-equiv/l) } & \multicolumn{5}{|c|}{ Mean Net Transport Rates (m-equiv or $m l / h o u r / 30 \mathrm{~cm}$ ) } \\
\hline & $\mathrm{Na}^{+}$ & $\boldsymbol{K}^{+}$ & $\mathrm{Cl}^{-}$ & $\mathrm{HCO}_{8}^{-}$ & $\mathrm{Na}^{+}$ & $K^{+}$ & $\mathrm{Cl}^{-}$ & $\mathrm{HCO}_{3}^{-}$ & $\mathrm{H}_{2} \mathrm{O}$ \\
\hline $\begin{array}{l}\text { Control } 1 \\
\text { Control } 2\end{array}$ & $\begin{array}{l}139.22 \pm 1.08 \\
138.2 \pm 0.83\end{array}$ & $\begin{array}{l}5.42 \pm 0.08 \\
5 \cdot 11 \pm 0.1\end{array}$ & $\begin{array}{l}119 \cdot 2 \pm 1 \cdot 75 \\
105 \cdot 4 \pm 2 \cdot 45\end{array}$ & $\begin{array}{l}21 \cdot 34 \pm 1 \cdot 82 \\
34.85 \pm 3 \cdot 8\end{array}$ & $\begin{array}{l}-5 \cdot 81 \pm 3 \cdot 2 \\
-13 \cdot 7 \pm 1 \cdot 3\end{array}$ & $\begin{array}{l}-0.25 \pm 0.18 \\
-0.6 \pm 0.6\end{array}$ & $\begin{array}{l}+0.48 \pm 3.0 \\
-4.0 \pm 0.8\end{array}$ & $\begin{array}{l}-7.34 \pm 0.6 \\
-9.96 \pm 0.55\end{array}$ & $\begin{array}{l}-49 \cdot 26 \pm 21 \cdot 1 \\
-102 \cdot 1 \pm 8 \cdot 6\end{array}$ \\
\hline$S_{\text {ignificance }}$ & NS & NS & $P<0.01$ & $P<0.05$ & $P<0.05$ & $P<0.05$ & NS & $\mathbf{P}<0.01$ & $\mathbf{P}<0.05$ \\
\hline
\end{tabular}

Table IV Results of two consecutive control studies (study 3) in which a higher bicarbonate concentration was present in the second period, no secretin being given $(n=10)$

\begin{tabular}{|c|c|c|c|c|c|c|c|c|c|}
\hline & \multicolumn{4}{|c|}{ Mean Concentrations (m-equiv/l) } & \multicolumn{5}{|c|}{ Mean Net Transport Rates (m-equiv/hour/30 cm) } \\
\hline & $\mathrm{Na}^{+}$ & $\boldsymbol{K}^{+}$ & $\mathrm{Cl}^{-}$ & $\mathrm{HCO}_{3}^{-}$ & $\mathrm{Na}^{+}$ & $\boldsymbol{K}^{+}$ & $\mathrm{Cl}^{-}$ & $\mathrm{HCO}_{3}^{-}$ & $\mathrm{H}_{2} \mathrm{O}$ \\
\hline $\begin{array}{l}\text { Control } \\
\text { Secretin }\end{array}$ & $\begin{array}{l}133 \pm 1 \cdot 29 \\
139 \cdot 5 \pm 1 \cdot 1\end{array}$ & $\begin{array}{l}5.63 \pm 0.2 \\
4.94 \pm 0.05\end{array}$ & $\begin{array}{l}116 \cdot 4 \pm 1 \cdot 62 \\
117 \cdot 1 \pm 2 \cdot 21\end{array}$ & $\begin{array}{l}20 \cdot 35 \pm 2 \cdot 75 \\
25 \cdot 31 \pm 2 \cdot 81\end{array}$ & $\begin{array}{l}-12 \cdot 1 \pm 2 \\
-5 \cdot 2 \pm 2.6\end{array}$ & $\begin{array}{l}-0.64 \pm 0.11 \\
-0.23 \pm 0.12\end{array}$ & $\begin{array}{l}-6 \cdot 3 \pm 1 \cdot 5 \\
+1 \cdot 59+2\end{array}$ & $\begin{array}{l}-6.65 \pm 0.96 \\
-6.83 \pm 1.32\end{array}$ & $\begin{array}{l}-101 \cdot 1 \pm 14 \cdot 3 \\
-\quad 41 \cdot 7 \pm 16.8\end{array}$ \\
\hline Significance & $P<0.01$ & $P<0.01$ & NS & NS & $1<P<0.05$ & $0.1<P<0.05$ & $P<0.02$ & NS & $P<0.05$ \\
\hline
\end{tabular}

Table $\mathrm{V}$ Effect of secretin on transport rates (study 4) when an attempt was made to obtain similar mean bicarbonate concentrations in the jejunal lumen during the secretin and control periods as described in the text $(n=9)$ 


\begin{tabular}{|c|c|c|c|c|c|c|c|c|c|}
\hline & \multicolumn{4}{|c|}{ Mean Concentrations (m-equiv/l) } & \multicolumn{5}{|c|}{ Mean Net Transport Rates (m-equiv/hour/30 cm) } \\
\hline & $\mathrm{Na}^{+}$ & $\boldsymbol{K}^{+}$ & $\mathrm{Cl}^{-}$ & $\mathrm{HCO}_{3}^{-}$ & $\mathrm{Na}^{+}$ & $\boldsymbol{K}^{+}$ & $\mathrm{Cl}^{-}$ & $\mathrm{HCO}_{3}^{-}$ & $\mathrm{H}_{\mathbf{3}} \mathrm{O}$ \\
\hline $\begin{array}{l}\text { Control } \\
\text { Secretin }\end{array}$ & $\begin{array}{l}137 \cdot 3 \pm 1 \cdot 38 \\
140 \cdot 3 \pm 0.95\end{array}$ & $\begin{array}{l}5.07 \pm 0.34 \\
4.66 \pm 0.23\end{array}$ & $\begin{array}{l}117 \cdot 8 \pm 1 \cdot 37 \\
113 \cdot 7 \pm 2 \cdot 14\end{array}$ & $\begin{array}{l}21 \cdot 98 \pm 1 \cdot 85 \\
29 \cdot 2 \pm 2 \cdot 49\end{array}$ & $\begin{array}{l}-10.5 \pm 2 \\
-13.7 \pm 2.6\end{array}$ & $\begin{array}{l}-0.49 \pm 0.08 \\
-0.53 \pm 0.12\end{array}$ & $\begin{array}{l}-4 \cdot 3 \pm 1 \cdot 4 \\
-5 \cdot 24 \pm 2 \cdot 7\end{array}$ & $\begin{array}{l}-6.38 \pm 0.58 \\
-8.41 \pm 1.17\end{array}$ & $\begin{array}{r}-81 \cdot 1 \pm 13.5 \\
-100 \cdot 2 \pm 17 \cdot 7\end{array}$ \\
\hline Significance & NS & NS & NS & NS & NS & NS & NS & NS & NS \\
\hline
\end{tabular}

Table VI Effect of secretin on transport rates in the mid jejunum (study 5) $(n=8)$

the influence of secretin in this mid region of the jejunum. The results (table VI) indicate that secretin did not influence electrolyte and water transport in the mid jejunum.

In the five tests of study 2 , total bile salt concentrations, measured in the solution entering the test segment, were low and there was no significant difference between the concentration in the control period and that in the secretin period (table VII).

\begin{tabular}{lll}
\hline & \multicolumn{2}{l}{ Bile Salt Concentration $(\mathrm{mM})$} \\
\cline { 2 - 3 } & Control & Secretin \\
\hline 1 & 0.86 & 0.03 \\
2 & 0.6 & 0.83 \\
3 & 0.73 & 0.63 \\
4 & 0.85 & 0.72 \\
5 & 0.6 & 0.65 \\
\hline
\end{tabular}

Table VII Bile salt concentrations in samples of fluid entering the test segment of intestine during a control period and during secretin infusion

\section{Discussion}

The present studies demonstrate that secretin in a dose recognized as being sufficient to produce a near maximal pancreatic response and likely, therefore, to be a near-physiological dose (Wormsley, 1968) reduces absorption of sodium and chloride ions and water in the proximal jejunum but has little effect on bicarbonate transport. This effect was noted even when a bicarbonate-rich fluid from the pancreas raised the concentration of bicarbonate in the lumen during secretin infusion. An increase in the luminal bicarbonate concentration, in the absence of secretin, enhanced ion and water absorption and the reduced absorption observed with secretin thus cannot be due to this change. This suggestion was confirmed in the studies in which the luminal bicarbonate concentration was maintained at similar levels during both the control period and the period of secretin infusion. One factor which was not controlled in these studies was the rate at which the perfusion fluid flowed down the jejunum. During the control period of the studies shown in table IV the mean flow rate was $7.84 \mathrm{ml} / \mathrm{min}$, while during the secretin infusion it was $13.4 \mathrm{ml} / \mathrm{min}$, and these differences were presumably due to a combination of the addition of pancreatic secretion to the test fluid and the reduced jejunal absorption during the secretin infusion. It is unlikely, however, that this increased flow rate was responsible for the reduced absorption during secretin administration since increases in flow rate over this range seem more likely to increase rather than decrease absorption rates (Sladen and Dawson, 1968; Dawson and McMichael, 1968).

It is of interest that secretin was apparently without effect in the mid jejunum and its influence thus seems to be sharply limited to an area in the proximal jejunum. The possibility arises that the effect of secretin was produced by stimulation of Brunner's glands secretion (Stening and Grossman, 1969). However, it seems unlikely that Brunner's glands are present in the jejunum in sufficient numbers to produce the effects noted here.

Bile salts, which might influence ion transport in the jejunum (Harris and Sladen, 1972), could theoretically have entered the test segment in increased amounts during the secretin infusion and caused the changes reported here. However, these changes could not have been due to bile salts since their concentrations were similar in the control and secretin periods.

These observations in the proximal jejunum are apparently similar to those described by Mekhjian et al (1972) and Moritz et al (1972) in recently published abstracts. However, Modigliani et al (1971) were unable to detect any effect of secretin on human jejunal ion transport. This discrepancy is difficult to explain but may be in part due to differences in experimental technique; their perfusion system utilized a proximal occlusive balloon in an attempt to avoid contamination with pancreatic juice and their perfusion fluid contained glucose. Gardner et al (1967) showed that secretin inhibited sodium chloride absorption in everted hamster gut sacs but Barbezat and Grossman (1971) were unable to detect an effect in vivo in dogs. Differences in technique and species may account for these discrepancies.

These studies do not provide an indication of the mechanisms involved in the reduction in absorption observed here. One can speculate, however, on two 


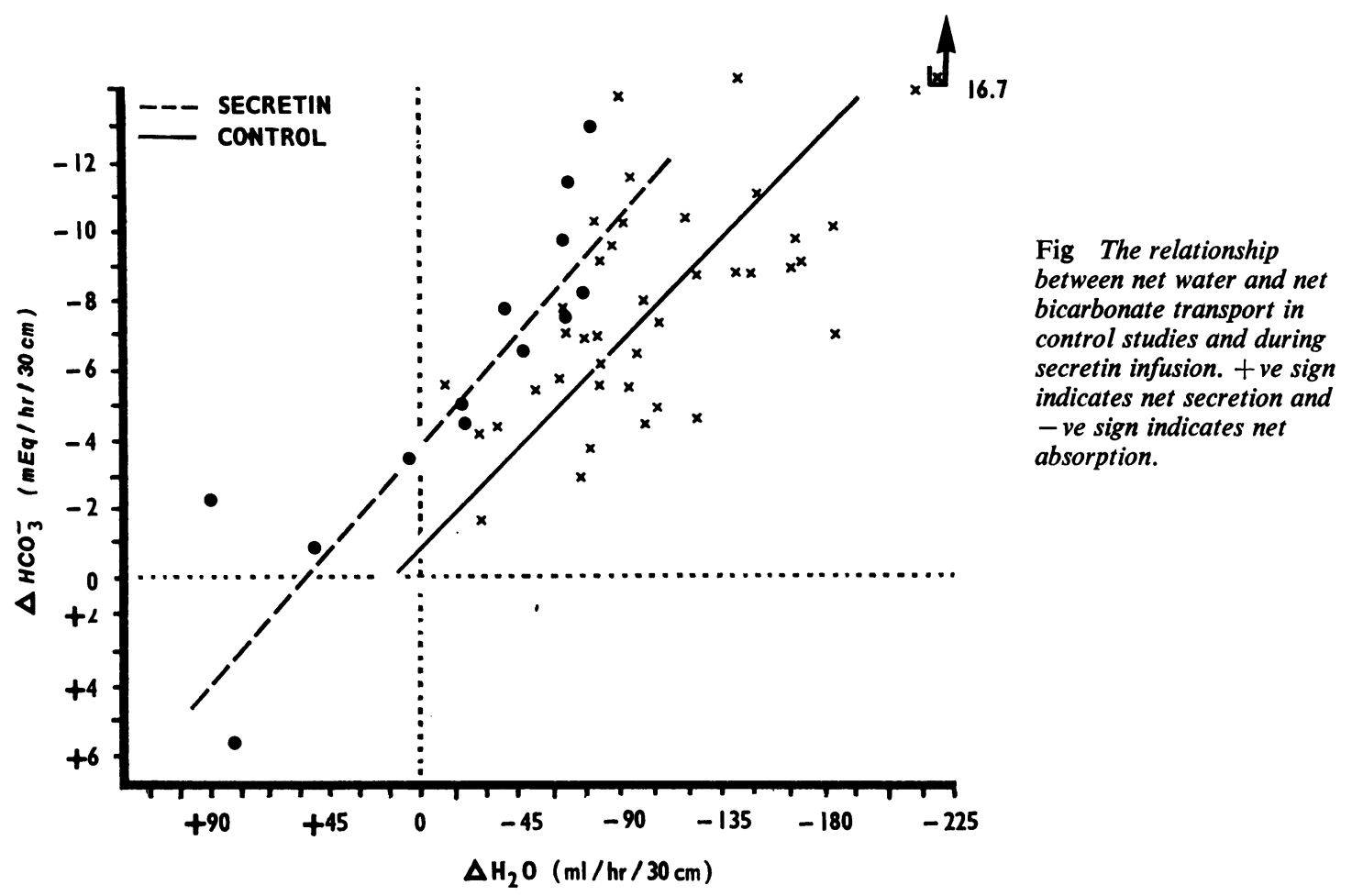

possibilities. The first is a direct inhibition of an active process for sodium and/or chloride absorption but Fordtran, Rector, and Carter (1968) suggest that sodium chloride absorption is a predominantly passive process in the human jejunum and postulate that bicarbonate enhances sodium absorption via a sodium/hydrogen exchange (Turnberg, Fordtran, Carter, and Rector, 1970). On this basis the finding that bicarbonate absorption was uninfluenced by secretin suggests that the sodium/ hydrogen exchange was also unaffected. The reduced net absorption is likely in these circumstances to have been produced by stimulation of a sodium chloride secretory process against a background of continuing normal bicarbonate absorption. The figure demonstrates the relationship between bicarbonate and water absorption in the presence and absence of secretin. For a given amount of bicarbonate absorbed less water was absorbed when secretin was infused than in the control situation, a finding which fits in either with the idea of a sodium chloride secretion occurring in the presence of normal sodium bicarbonate absorption or with the inhibition of a non-bicarbonate-dependent active sodium chloride absorptive process.

Intestinal blood flow and motility were not measured in these studies and the possibility that changes in either of these functions could have contributed to the alterations in transport produced by secretin cannot be excluded.

The physiological significance of this reduction in net absorption of salt and water induced by secretin is uncertain. Secretin may exert a fine control on the rate of absorption and prevent the too rapid dehydration of upper jejunal contents which could, theoretically, interfere with adequate mixing and digestion.

We are grateful for generous support received for these studies from the Research Grants Committee of the Board of Governors of the United Manchester Hospitals and from the Medical Research Council. We are indebted to Mrs Riley for her expert typing of this manuscript and to the Department of Medical Illustration of the Manchester Royal Infirmary for the figure.

\section{References}

Barbezat, G. O., and Grossman, M. I. (1971). Intestinal secretion: stimulation by peptides. Science, 174, 422-423.

Cooper, H., Levitan, R., Fordtran, J. S., and Ingelfinger, F. J. (1966). A method for studying absorption of water and solute from the human small intestine. Gastroenterology, 50, 1-7.

Dawson, A. M., and McMichael, H. B. (1968). The effect of flow rate on glucose absorption demonstrated by perfusion studies in rat jejunum in vivo. J. Physiol. (Lond.), 196, 32P-33P.

Fordtran, J. S., Rector, F. C., Jr., and Carter, N. W. (1968). The 
mechanisms of sodium absorption in the human small intestine. J. clin. Invest., 47, 884-900.

Gardner, J. D., Peskin, G. W., Cerda, J. J., and Brooks, F. P. (1967). Alterations of in vitro fluid and electrolyte absorption by gastrointestinal hormones. Amer. J. Surg., 113, 57-64.

Harries, J. T., and Sladen, G. E. (1972). The effects of different bile salts on the absorption of fluid, electrolytes and monosaccharides in the small intestine of the rat in vivo. Gut, 13, 596603.

Hyden, S. (1956). A turbidometric method for the determination of higher polyethylene glycols in biological materials. $K$. LantbrHögsk. Annlr., 22, 139-145.

Johnson, L. R., and Grossman, M. I. (1971). Intestinal hormones as inhibitors of gastric secretion. Gastroenterology, 60, 120-144.

Jonson, G., Sundman, L., and Thulin, L. (1964). The influence of chemically pure secretin on hepatic bile output. Acta physiol. scand., 62, 287-290.

Mekhjian, H., King, D., Sanzenbacher, L., and Zollinger, R. (1972). Glucagon (Gl) and secretin (Se) inhibit water and electrolyte transport in the human jejunum. Gastroenterology, 62, 782(a).

Modigliani, R., Huet, P. M., Rambaud, J. C., and Bernier, J. J. (1971). Effect of secretin upon movement of water and electrolytes across the small intestine in man. Rev. europ. Etud. clin. biol., 16, 361-364.

Moritz, M., Finkelstein, G., Meshkinpour, H., Fingerut, J., Siplet, H., and Lorber, S. H. (1972). The effect of secretin and cholecystokinin on transport of electrolyte and water in human jejunum. Gastroenterology, 62, 856(a).

Sladen, G. E., and Dawson, A. M. (1968). An evaluation of perfusion techniques in the study of water and electrolyte absorption in man: the problem of endogenous secretions. Gut, 9, 530-535.

Stening, G. F., and Grossman, M. I. (1969). Hormonal control of Brunner's glands. Gastroenterology, 56, 1047-1052.

Turnberg, L. A., and Anthony-Mote, A. (1969). The quantitative determination of bile salts in bile using thin-layer chromatography and $3 \alpha$ hydroxysteroid dehydrogenase. Clin. chim. Acta, 24, 253-259.

Turnberg, L. A., Fordtran, J. S., Carter, N. W., and Rector, F. C., Jr. (1970). Mechanism of bicarbonate absorption and its relationship to sodium transport in the human jejunum. $J$. clin. Invest., 49, 548-556.

Wormsley, K. G. (1968). Response to secretin in man. Gastroenterology, 54, 197-209. 